\title{
ИСПОЛЬЗОВАНИЕ СУПРАМОЛЕКУЛЯРНЫХ КОМПЛЕКСОВ ТЕБУКОНАЗОЛА С ЭКСТРАКТОМ КОРНЕЙ СОЛОДКИ ДЛЯ КОНТРОЛЯ ОБЫКНОВЕННОЙ КОРНЕВОЙ ГНИЛИ В ПОСЕВАХ ЯРОВОЙ ПШЕНИЦЫ
}

\section{Теплякова О.И., Власенко Н.Г.}

Сибирский федеральный научный центр агробиотехнологий Российской академии наук, p.n. Краснообск, Россия, e-mail: vlas_nata@ngs.ru

Abstract: The fungicidal activity of tebuconazole supramolecular complexes with licorice root extract used as a spring wheat seed protectant was evaluated. Their single use at the stage of preparation 
for sowing made it possible to effectively control the development and prevalence of common root rot during the growing season. The strength of the fungicidal effect depended on the rate of consumption of complexes. All tested compounds provided increased density of standing crops, plant survival for harvesting and grain productivity of the crop.

Keywords: soft spring wheat, common root rot, supramolecular complexes, tebuconazole, licorice root extra.

\section{Введение}

Защита растений - основной фактор, определяющий уровень возможных рисков снижения продуктивности зерновых агроэкосистем. Уровень рентабельности производства значительно возрастает в оптимизированных по фитосанитарным показателям условиях. Среди множества методов и средств борьбы с вредными организмами наилучший оздоравливающий эффект достигается химическими средствами [1]. В рамках экологизации защиты растений в РФ [2,3] и за рубежом [4, 5] ведется разработка нанобиотехнологий, позволяющих создавать биоактивные наноструктуры и средства доставки действующего вещества агрохимикатов. Наноструктурные формы позволяют уменьшить расход фунгицидов, сохраняя его биологическую эффективность [6] и их рассматривают в качестве средств для борьбы с фитопатогенами [7]. В Сибири путем механохимической модификации широко распространённого действующего вещества тебуконазол созданы его комплексы с водорастворимыми полимерами [8]. В качестве одного из веществ, способных формировать супрамолекулярные системы с тебуконазолом, использован сухой экстракт корней солодки [9].

Цель настоящих исследований - оценить фунгицидную активность супрамолекулярных комплексов тебукозола с экстрактом корней солодки в качестве протравителя семян для снижения развития и распространенности обыкновенной корневой гнили в посевах яровой мягкой пшеницы.

\section{Материалы и методы}

Эксперименты проведены в 2018-2019 гг. на опытном поле СибНИИЗиХ СФНЦА РАН в центральной лесостепи Новосибирской области. Почва - чернозем выщелоченный среднесуглинистый среднемощный. В экспериментах использована мягкая яровая пшеница сорта Новосибирская 31. Посев произведен по пару с нормой высева 6,5 млн. всхожих зерен/га. Опыт включал 7 вариантов: 1 - контроль без обработки семян фунгицидами; 2 - обработка семян фунгицидом Раксил, КС (д.в. тебуконазол, 60 г/л) с нормой расхода 0,5 л/т; 3 - обработка семян фунгицидом Раксил, КС с нормой расхода 0,25 л/т; 4 - обработка семян супрамолекулярным комплексом тебуконазола с экстрактом корней солодки Glycyrrhiza uralensis в соотношеии 1:10, по массе, ВМ 24 час, норма расхода препарата 0,3 кг/т; 5 - обработка семян супрамолекулярным комплексом тебуконазола с экстрактом корней солодки = 1:10, по массе, ВМ 24 час; норма расхода препарата 0,15 кг/т; 6 - обработка семян супрамолекулярным комплексом тебуконазола экстрактом корней солодки = 1:5, по массе, ВМ 24 час, норма расхода препарата 0,15 кг/т; 7 - обработка семян супрамолекулярным комплексом тебуконазола с экстрактом корней солодки = 1:5, по массе, ВМ 24 час, норма расхода препарата 0,075 кг/т. Протравливание проводилось с увлажнением - 10 л/т семян. Площадь делянки в 2018 г. - 21,45 м², 2019 г. 10,2 м², повторность, соответственно - четырех и восьмикратная, размещение систематическое. Оценку фитосанитарного состояния корневой системы яровой пшеницы [10] проводили в динамике, начиная с фазы 2-х листьев. С каждого варианта отбирали по 100 растений $(10 \times 10$ точек /делянка). Математическую обработку данных осуществляли при помощи пакета прикладных программ “СНЕДЕКОР” [11]. 


\section{Результаты и обсуждение}

Созданные в Институте химии твердого тела и механохимии СО РАН фунгицидные комплексы тебуконазола с экстрактом корней солодки для использования в качестве протравителей семян достоверно контролировали распространение и развитие обыкновенной корневой гнили мягкой яровой пшеницы, как на первых этапах органогенеза, так и в более поздний период развития. В самый уязвимый период всходы 2 листа лучший фунгицидный эффект в среднем за два года (2018-2019) показали два комплекса - тебуконазол : экстракт корней солодки с соотношением 1:5 и 1:10, использованные с нормой расхода 0,15 кг/т. Биологическая эффективность первого достигала 73,5, второго - 72,5\% (эффективность химического эталона Раксил $=51,5$ $56,5 \%)$.

Таблица - Развитие и распространенность обыкновенной корневой гнили в посевах яровой мягкой пшеницы Новосибирская 31рот обработке семян комплексами тебуконазола с экстрактом корней солодки (средние за 2018-2019 г.)

\begin{tabular}{|l|c|c|c|c|}
\hline \multirow{2}{*}{ Вариант } & \multicolumn{2}{|c|}{5 листьев } & \multicolumn{2}{|c|}{ Молочная спелость зерна } \\
\cline { 2 - 5 } & $\begin{array}{c}\text { индекс } \\
\text { развития } \\
\text { болезни, } \\
\%\end{array}$ & $\begin{array}{c}\text { распростра } \\
\text { ненность } \\
\text { болезни, \% }\end{array}$ & $\begin{array}{c}\text { индекс } \\
\text { развития } \\
\text { болезни, \% }\end{array}$ & $\begin{array}{c}\text { распростра } \\
\text { ненность } \\
\text { болезни, \% }\end{array}$ \\
\hline Контроль & 36,5 & 93,5 & 42,3 & 99,5 \\
\hline Раксил, КС, 0,5 л/т & 21,7 & 75,0 & 25,5 & 85,0 \\
\hline Раксил, КС, 0,25 л/т & 19,6 & 73,5 & 23,5 & 77,0 \\
\hline $\begin{array}{l}\text { Тебуконазол : экстракт корней } \\
\text { солодки = 1:10, 0,3 кг/т }\end{array}$ & 15,4 & 59,0 & 23,0 & 79,5 \\
\hline $\begin{array}{l}\text { Тебуконазол : экстракт корней } \\
\text { солодки = 1:10, 0,15 кг/т }\end{array}$ & 17,5 & 65,5 & 29,3 & 93,0 \\
\hline $\begin{array}{l}\text { Тебуконазол : экстракт корней } \\
\text { солодки = 1:5, 0,15 кг/т }\end{array}$ & 14,0 & 52,5 & 23,8 & 76,5 \\
\hline $\begin{array}{l}\text { Тебуконазол: экстракт корней } \\
\text { солодки = 1:5, 0,075 кг/т }\end{array}$ & 22,0 & 77,5 & 26,0 & 86,5 \\
\hline НСР 05 & 1,16 & 2,26 & 0,91 & 3,60 \\
\hline Степень влияния по Снедекору, \% & 98,9 & 98,7 & 99,2 & 82,5 \\
\hline
\end{tabular}

Во всех вариантах с применением супрамолекулярных комплексов симптомы заболевания фиксировали только на формирующихся корнях, прикорневая часть в этой фазе не поражалась. На этапе раннего кущения все фунгицидные комплексы надежно защищали подземное междоузлие, снижая его заболеваемость в 13,4-3,8 (тебуконазол : экстракт корней солодки $=1: 10$ ) и $8,2-1,4$ раза (тебуконазол : экстракт корней солодки $=1: 5$; Раксил 0,5 и 0,25 л/т - в 2,8 и 3,1 раза; индекс развития в контроле $=5,4 \%)$ и влагалища прикорневых листьев - в 3,3-2,9 и 4,0-3,1 раза (Раксил 0,5 и 0,25 л/т - в 3,4 и 1,8 раза) индекс развития в контроле $=31,9 \%$. У кустящихся защищенных растений сформировалась более здоровая вторичная корневая система: индексы развития болезни от использования состава тебуконазол: экстракт корней солодки $=1: 10,0,3$ и 0,15 кг/т снижались в 5,8 и 19,3, тебуконазол: экстракт корней солодки $=1: 5,0,15$ и 0,075 кг/ - в 14,8 и 9,1 раза (Раксил КС, $0,5$ и 0,25 л/т - в 18,8 и 9,1 раза; в контроле индекс развития $=7,4 \%)$. Сниженные 
показатели развития и распространенности обыкновенной корневой гнили в опытных вариантах наблюдали в фазе 5 листьев и молочной спелости зерна (табл.). Встречаемость растений с симптомами заболевания заметно уменьшалась (биологическая эффективность 28 и 41\%), если семена обрабатывали опытными фунгицидными комплексами тебуконазол : экстракт корней солодки $=1: 10$ и 1:5, с нормой расхода 0,15 кг/т (Раксил 0,5 и 0,25 - на 18,5 и 20\%). Интенсивность развития болезни в фазе 5 листьев эффективнее контролировали более высокие нормы расхода препаратов: тебуконазол : экстракт корней солодки $=1: 10$ с нормой расхода 0,3 кг/т снижал индекс в 2,4, в соотношении 1:5 с нормой расхода 0,15 кг/т - в 2,6 раза. Их половинные нормы расхода снизили заболеваемость в 2,1 и 1,7 раза, и их оздоровительный эффект не уступал эталонному протравителю - в 1,7-1,9 раза.

В фазе молочной спелости зерна развитие обыкновенной корневой гнили в опытных вариантах по-прежнему оставалось ниже контрольного показателя - в 1,8-1,4 (тебуконазол : экстракт корней солодки $=1: 10,0,3$ и 0,15 кг/т) и 1,8-1,6 раза (тебуконазол: экстракт корней солодки $=1: 5,0,15$ и 0,075 кг/т); что было на уровне эталона $-1,6$ и 1,8 раза.

В сложившейся фитосанитарной ситуации формировался более плотный по густоте стояния посев пшеницы. Число растений, выросших из семян, защищенных фунгицидными комплексами тебуконазола с соотношением 1:10 (0,3 и 0,15 кг/т) и 1:5 $(0,15$ и 0,075 кг/т) на 1 м2 возрастало на 15,0-6,4 и 9,6-9,2\%, в варианте с Раксилом, 0,5 и 0,25 л/т - на 4,8 и 7,2 (в контроле число растений составило 500 шт./м2). Выживаемость к уборке также была выше на 10,6-11,4 и 10,9-10,1\%, соответственно, при показателе в контроле 81,4\%. В варианте с Раксилом, 0,5 и 0,25 л/т выживаемость растений повысилась на 9,2 и 8,5\%. Полученные в опытных вариантах прибавки урожая зерна $(0,52$ и 0,62 т/га - тебуконазол:экстракт корней солодки $=1: 10,0,3$ и 0,15 кг/т; 0,59 и 0,68 т/га - тебуконазол:экстракт корней солодки $=1: 5,0,15$ и 0,075 кг/т) значительно превышали (в 2,1 и 1,4; 2,4 и 1,6 раза) таковые от обработки семян коммерческим фунгицидом Раксил, КС, который повысил урожайность на 0,25 и 0,43 т/га соответственно нормам расхода 0,5 и 0,25 л/т (в контроле урожайность составила 5,13 т/га; $\left.\mathrm{HCP}_{05}=0,06\right)$.

\section{Выводы}

Однократное использование фунгицида тебуконазол в форме супрамолекулярных комплексов с экстрактом корней солодки на этапе подготовки посевного материала позволяет эффективно контролировать развитие и распространенность обыкновенной корневой гнили во время вегетации яровой мягкой пшеницы. Защита от семенной и почвенной инфекций обеспечивает повышение густоты стояния всходов, выживаемости растений и их зерновой продуктивности. Полученные фитосанитарный и экономический эффекты испытанных норм расхода фунгицидов-протравителей позволяют отнести их к препаратам с улучшенными экологическими и биологическими свойствами, уменьшающих расход фунгицида, повышающих зерновую продуктивность культуры не ниже, чем коммерческий фунгицид Раксил, КС с рекомендуемой нормой расхода 0,5 л/т семян.

\section{Библиография}

1. Захаренко В.А. Экономическая целесообразность системы защиты зерновых культур в России//Достижения науки и техники АПК. 2018. Т.32. №7. С. 5-8. DOI: 10.24411/0235-2451-2018-10701. 
2. Яппаров Д.А., Яппарова Л.М., Яппаров И.А., Ежкова Д.О. Перспективность использования нанотехнологий в сельском хозяйстве // Материалы IX Международного симпозиума НП «Содружество ученых агрохимиков и агроэкологов». Казань, 09-12 июня 2017. С. 80-83.

3. Егоров Н.П., Шафронов О.Д., Егоров Д.Н., Сулейманов Е.В. Разработка и проведение экспериментальной оценки эффективности применения в растениеводстве новых видов удобрений, полученных с использованием нанотехнологий //Вестник Нижегородского университета им. Н.И. Лобачевского. 2008. № 6. С. 94-99.

4. Жданок С.А. Ильина 3.М., Толочко Н.К. Нанотехнологии в агропромышленном комплексе: монография, под ред. Н.К. Толочко. Минск: БГАТУ, 2012. 172 с.

5. Banik S., Pérez-de-Luque A. In vitro effects of copper nanoparticles on plant pathogens, beneficial microbes and crop plants // Spanish Journal of Agricultural Research. 2017. V. 15. Issue 2. e1005. Https: //doi.org/10.5424/sjar/2017152-10305.

6. Захаренко В.А. Нанофитосанитария - научное направление, объединяющее нанотехнологию и современную защиту растений. Часть 1. Общая концепция //Агрохимия. 2011. № 3. C. 3-16.

7. Mishra S., Singh B.R, Singh A., Keswani C., Naqvi A.H., et al. Biofabricated silver nanoparticles act as a strong fungicide against Bipolaris sorokiniana causing spot blotch disease in wheat // PLoS ONE. 2014. 9(5): e97881. DOI: 10.1371/journal.pone.0097881.

8. Теплякова О.И., Власенко Н.Г., Душкин А.В., Метелева Е.С., Халиков С.С. Инновационные препараты для защиты яровой пшеницы в условиях Сибири // Научные инновации - аграрному производству: материалы Междунар. науч.- практич. конф. посвящ. 100-летнему юбилею Омского ГАУ (21 февраля 2018 года) - Омск: ФГБОУ ВО Омский ГАУ. С.1086-1091.

9. Власенко Н.Г., Теплякова О.И. Душкин А.В. Контроль болезней листьев мягкой яровой пшеницы супрамолекулярным комплексом тебуконазола с экстрактом солодки //Материалы Межд. научн. конф. "Защита растений в традиционном и экологическом земледелии" в рамках проекта «Укрепление региональных возможностей применения экологических технологий в интегрированных системах. борьбы с вредителями». Кишинев, республика Молдова, 10-12 декабря 2018. С. 131-134.

10. Тепляков Б.И. Обыкновенная корневая гниль яровой пшеницы на чернозёмах в лесостепной зоне Западной Сибири //Новосиб. гос. аграр. ун-т. Новосибирск. 2012. 122. 11. Сорокин О.Д. Прикладная статистика на компьютере. 2-е изд. Новосибирск. 2012. $282 \mathrm{c}$. 